\title{
Korelasi Pemahaman Konsep Salat dengan Kedisiplinan Peserta Didik
}

\section{Correlation Understanding Prayer Concept the Discipline of Students}

\author{
Ai Ilis \\ Sekolah Tinggi Agama Islam (STAI) Syamsul 'Ulum Gunungpuyuh \\ Sukabumi, Jawa Barat, Indonesia \\ ai.ilis.2401@gmail.com
}

\begin{abstract}
Abstrak
Kajian ilmiah ini membahas mengenai pemahaman konsep salat terhadap kedisiplinan peserta didik. Penelitian bertujuan untuk mengetahui sejauh mana korelasi antara pemahaman konsep salat terhadap kedisiplinan di kalangan peserta didik. Metode yang digunakan dalam penelitian ini yaitu metode kuantitatif. Populasi dalam penelitian ini adalah seluruh peserta didik SMP Negeri 2, SMP Negeri 4 dan SMP Negeri 21 Kota Samarinda tahun pelajaran 2017/2018, berjumlah 2.745 responden. Sampel yang diambil dengan teknik klaster berdasarkan letak daerahnya sebesar 96 peserta didik dengan menggunakan rumus Taro Yamane. Teknik analisa data menggunakan analisis statistik dengan teknik regresi. Hasil penelitian menunjukkan bahwa pemahaman konsep salat secara parsial memiliki korelasi yang kuat dengan kedisiplinan peserta didik. Implikasinya salat mengajarkan kedisiplinan pada aturan, oleh karena itu penting memahami makna salat, menegakkan salat dengan sebaikbaiknya dan menerapkan dalam kehidupan.
\end{abstract}

Kata kunci: Kedisiplinan, Konsep Salat, Peserta Didik

\begin{abstract}
This scientific research discusses the understanding of the concept of salat to the discipline of students. This research aims to determine the extent of correlation between the understanding of the concept of salat to discipline among students. The method of research used quantitative method. The population in this research were all students of SMP Negeri 2, SMP Negeri 4 and SMP Negeri 21 Samarinda City in the academic year 2017/2018, totality 2,745 respondent. Samples taken by clustering techniques based on the location of the area of 96 students use the Taro Yamane formula. Data analysis techniques used statistical analysis with regression techniques. Based on the research, the understanding of concept of salat partially has a strong correlation with the discipline of students. The implication is prayer teachs discipline in rules, therefore it is important to understand the meaning of salat, establish prayer as well as possible and apply it in life.
\end{abstract}

Keywords: Concept of Salat, Discipline, Students

Jurnal at-Tadbir Vol. 29 No. 02 Juli 2019 


\section{PENDAHULUAN}

Manusia adalah makhluk yang paling istimewa dan berbeda dengan makhluk yang lain. Adapun yang membedakan manusia dengan makhluk lainnya adalah manusia memiliki ilmu pengetahuan, budi pekerti, akal, dan budaya. Dengan demikian untuk mempertahankan itu semua dan menjalani proses kehidupannya manusia membutuhkan pendidikan. Pendidikan Agama Islam merupakan bagian yang tidak terpisahkan dari Sistem Pendidikan Nasional keberadaannya sangat penting untuk membentuk Pendidikan Nasional dalam membentuk insan yang beiman dan bertakwa kepada Allah SWT. Sebagaimana tertuang di UU No.20 pada Tahun 2003 di Bab II pada Pasal 3 tentang Pendidikan Nasional.

Pendidikan berfungsi mengembangkan kemampuan dan membentuk watak serta peradaban bangsa yang bermartabat dalam rangka mencerdaskan kehidupan bangsa, bertujuan untuk berkembangnya potensi peserta didik agar menjadi manusia yang beriman dan bertakwa kepada Tuhan Yang Maha Esa, berakhlak mulia, sehat berilmu, cakap kreatif, mandiri dan menjadi warga negara yang demokratis serta bertanggungjawab.

(Sistem Pendidikan Nasional, 2003).

Pedidikan Agama Islam merupakan pendidikan melalui ajaran-ajaran Islam yang merupakan bimbingan dan arahan pada peserta didik supaya nantinya sesudah selesai dari pendidikan, peserta didik mampu memahami, menghayati kemudian mengamalkan ajaran Agama yang sudah diyakininya dengan menyeluruh, dengan menjadikan ajaran tersebut sebagai suatu pedoman hidupnya untuk keselamatan juga kesejahteraan 
hidup baik di dunia maupun di akhirat” kelak (Daradjat, 2011).

Pendidikan dilakukan dengan sadar dan terencana sebagaimana tercantum dalam UUSPN No.20 tahun 2003 Bab 1 Pasal 1. Pendidikan dapat diartikan sebagai "usaha sadar dan terencana untuk mewujudkan suasana belajar dan proses pembelajaran agar peserta didik secara aktif mengembangkan potensi dirinya untuk memiliki kekuatan spiritual keagamaan, pengendalian diri, kepribadian kecerdasan, akhlak mulia, serta keterampilan yang diperlukan dirinya, masyarakat, bangsa dan Negara"(Sistem Pendidikan Nasional, 2003).

Pendidikan Agama Islam merupakan usaha sadar yaitu suatu kegiatan berupa bimbingan, pengajaran dan latihan yang dilakukan dengan berencana dan sadar atas tujuan yang mau dicapai, dengan tujuan supaya meningkatkan kepercayaan, pemahaman, penghayatan juga pengamalan pendidikan agama Islam oleh peserta didik, disamping supaya membentuk kesalehan pribadi, juga supaya membentuk kesalehan sosial (Muhaimin, 2002).

Secara utuh tujuan pendidikan harus mampu menghasilkan pribadi yang mempunyai pribadi yang cerdas dan religius. Maka dari itu betapa pentingnya pemahaman materi Pendidikan Agama, kemudian yang merupakan salah satu faktor untuk membantu tercapainya maksud pendidikan tersebut adalah dengan memaksimalkan Pendidikan Agama Islam pada Sekolah yang didalamnya membahas tentang ibadah serta hukumnya. Peserta didik dituntut supaya mengerti dan memahami cara salat, hal yang dikaitkan dengannya seperti syarat sah, rukun, hal yang menyebabkan batalnya salat dan lain-lain. Materi ini merupakan suatu keharusan, 
karena salat termasuk ibadah yang wajib dilaksanakan oleh setiap muslim sampai akhir hayatnya. Sebagaimana (QS) Al-Ankabut (29): 45. "Dan dirikanlah salat. Sesungguhnya salat itu mencegah dari perbuatan keji dan mungkar"(Departemen Agama RI, 2009).

Adapun salah satu perintah Allah bagi umatnya yaitu melaksanakan salat, salat menurut bahasa adalah do'a, sedang menurut istilah salat merupakan ibadah yang disusun mulai beberapa perkataan maupun perbuatan yang diawali dengan takbir, kemudian diakhiri oleh salam dengan memperhatikan syarat yang ditentukan (Rasyid, 2007). Pada dasarnya tujuan salat sebagaimana tercantum dalam Alquran yaitu menjauhkan dari perilaku keji dan munkar. Salat yang kita kerjakan secara tidak langsung akan membuat hidup menjadi teratur dan menguatkan kemampuan serta sebagai latihan sekaligus memilki aspek-aspek spiritual, intelektual, moral, sosial dan fisik.

Seorang muslim yang memperhatikan kewajiban salat serta melaksanakan dengan sungguh-sungguh, akan membawanya menjadi pribadi yang tingkah lakunya terjaga. Dengan kewajiban salat yang telah diatur waktunya, jasmani maupun rohani akan ikut terlatih untuk menaati peraturan yang telah ditetapkan. Karena salat sebagai sarana untuk membiasakan diri menjadi disiplin dalam menaati peraturan yang telah ditentukan. Untuk meningkatkan kedisiplinan salah satunya ditunjang oleh pemahaman peserta didik pada konsep salat. Mereka yang memiliki pemahaman konsep salat yang tinggi maka akan berdampak baik kepada kedisiplinannya, akan tetapi peserta didik yang tidak memiliki pemahaman yang tinggi 
terhadap konsep salat maka kedisiplinan mereka tergolong rendah. Tingkat pemahaman konsep salat yang tinggi akan lebih menyadarkan kewajiban terhadap kedisiplinan tetapi pada kenyataannya masih ada diantara mereka yang memiliki tingkat pemahaman konsep salat yang baik tetapi memiliki kesadaran yang rendah dalam kedisiplinan.

Hal lain yang berhubungan dengan kedisiplinan peserta didik dapat dikatakan masih rendah dapat dilihat dari bagaimana euforia yang terjadi pada saat kelulusan sekolah, pada Sekolah Menengah Pertama maupun Sekolah Menengah Atas di kalangan peserta didik. Terjadinya perayaan yang berlebihan yang tidak sesuai dengan norma yang ada, arak-arakan dan corat-coretan seragam, serta pelanggaran aturanaturan berkendara dan tindakan tidak disiplin lain nya adalah bukti bahwa misi dari pendidikan belum terimplementasi dengan baik. Apa yang dilakukan peserta didik seolah-olah yang didapatkan dari sekolah tidak aplikatif dalam kehidupan untuk disiplin dalam kehidupan sehari-hari. Seperti ada kelainan antara teori di sekolah dengan praktik dalam kehidupan sehari-hari. Padahal jika memang pembelajaran yang di dapat dari sekolah seperti pemahaman konsep salat yang sudah baik, maka sudah sepantasnya kedisiplinannya pun akan bisa terlaksana dengan baik dalam kehidupan sehari-hari.

Berdasarkan studi pendahuluan, diperoleh keterangan dari salah satu guru Pendidikan Agama Islam pada Sekolah Mengengah Pertama di Samarinda, menyatakan pemahaman peserta didik pada konsep salat ini tergolong baik, ini terbukti pada proses pembelajaran berlangsung, dilihat dari keaktifan mereka pada proses pembelajaran berlangsung juga dapat dilihat pada saat bertanya dan menjawab baik soal 
lisan maupun tulisan. Selain itu juga terbukti dengan adanya pelakasanaan salat sunnah, pelaksanaan salat berjamaah yang dilaksanakan setiap hari pada waktu Zuhur dan Asar dengan bimbingan para guru. Fenomena tersebut menunjukkan tingginya pemahaman peserta didik pada konsep salat. Namun berdasarkan observasi awal, masih ada diantara mereka yang berprilaku tidak disiplin terhadap peraturan di sekolah. Dari fenomena di atas, terlihat adanya kesenjangan, satu sisi pemahaman konsep salat tergolong cukup tinggi namun disisi lain kedisiplinan mereka tergolong rendah.

Berdasarkan masalah di atas, sehingga penulis terdorong untuk meneliti lebih dalam permasalahan tersebut. Untuk mengetahui jawaban dari permasalahannya maka penulis akan melakukan penelitian lebih jauh dengan judul "Korelasi Pemahaman Konsep
Salat Terhadap Kedisiplinan Peserta Didik Sekolah Menengah Pertama di Kota Samarinda".

\section{METODE PENELITIAN}

A. Jenis Penelitian

Sukmadinata (2012) menyatakan bahwa Penelitian kuantitatif adalah penelitian yang memperoleh data melalui angka dan instrumen-instrumen yang dapat diukur. Adapun jenis penelitian yang digunakan adalah penelitian kuantitatif, dengan tujuan untuk memperoleh gambaran umum yang lebih objektif dan terukur. Metode kuantitatif yaitu metode pengujian teori atau konsep-konsep yang dihubungkan dengan realita kemudian memperlakukan data melalui pengolahan statistik. Melalui metode ini diharapkan mendapat gambaran tetang korelasi pemahaman konsep salat terhadap kedisiplinan peserta didik SMP di Kota Samarinda. 
B. Populasi dan Sampel

Populasi adalah wilayah generalisasi yang terdiri atas objek atau subjek yang mempunyai kualitas dan karakteristik tertentu yang ditetapkan oleh peneliti untuk dipelajari kemudian ditarik kesimpulan (Sukmadinata, 2012). Populasi merupakan sekumpulan individu yang memiliki karakteristik yang diperlukan dalam penelitian. Populasi pada penelitian ini adalah peserta didik yang beragama Islam di SMP Samarinda, dengan jumlah 81 Sekolah. Kemudian diambil 3 sekolah yang dianggap mewakili berdasarkan letak daerahnya dan menunjang penelitian, yaitu SMP Negeri 2 berjumlah 973 peserta didik, SMP Negeri 4 berjumlah 957 peserta didik dan SMP Negeri 21 berjumlah 815 peserta didik. Berdasarkan data tersebut jumlah populasi keseluruhan berjumlah 2.745 peserta didik.
Sampel merupakan bagian dari jumlah responden yang memiliki karakteristik populasi tersebut (Sugiyono, 2017). Teknik pengambilan sampel menggunakan cluster sampling (area sampling) yaitu pengambilan sampel berdasarkan letak daerah dari populasi yang ditetapkan. Sampel pada penelitian ini yaitu SMP Negeri 2, 4 dan 21 Samarinda. Diketahui bahwa jumlah populasi sebanyak 2.745 peserta didik. Adapun teknik dalam pengambilan sampel di dalam bukunya Riduwan (2015) yaitu dengan menggunakan rumus Taro Yamane atau Slovin sebagai berikut:

$n=\frac{N}{N \cdot d^{2}+1}$.

Berdasarkan rumus tersebut diperoleh jumlah sampel sebagai berikut: 


$$
\begin{aligned}
n=\frac{2745}{2745 \times 0.1^{2}+1} & \\
& =\frac{2745}{2745 \times 0.01+1} \\
& =\frac{2745}{28,45}=96,4 \\
& =96
\end{aligned}
$$

Adapun pengambilan sampel dari masing-masing SMP Samarinda dengan menggunakan rumus sebagai berikut:

$$
n i=\frac{N i}{N} \cdot n
$$

SMP Negeri 2 Samarinda = $975: 2745 \times 96=$

responden

SMP Negeri 4 Samarinda = $957: 2745 \times 96=$

responden

SMP Negeri 21 Samarinda = $815: 2745 \times 96=$

responden

Pemilihan sampel SMP Negeri 2, 4 dan 21 Samarinda adalah berdasarkan asumsi bahwa objek yang akan diteliti sangat luas, sehingga tidak memungkinkan untuk mengambil seluruh objek dengan mempertimbangkan tenaga, dana dan waktu. Adapun pelaksanaanya melalui tiga langkah, langkah pertama menentukan sampel sekolah dengan teknik claster sampling, langkah kedua menentukan responden di sekolah tersebut dengan sampling kuota, dan yang ketiga penyebaran angket dengan menggunakan sampling incidental (Sugiyono, 2017) yaitu peneliti menentukan sampel berdasarkan kebetulan.

C. Pengumpulan Data

Pada tahap ini, peneliti menggunakan tiga macam metode atau teknik pengumpulan data yang diperlukan dalam penelitian ini, yaitu Observasi, Dokumentasi dan Kuisioner (Angket).

Daryanto (2008) menyatakan bahwa observasi merupakan suatu pengamatan awal untuk memperoleh informasi yang dibutuhkan oleh peneliti terhadap objek yang akan diteliti dengan 
melakukan pencatatan secara sistematis. Teknik observasi yang dilakukan melalui pengamatan terlebih dahulu kepada objek yang akan diselidiki dengan sistematis dan mendalam untuk mengumpulkan data awal yang dibutuhkan pada kajian penelitian.

Dokumentasi adalah suatu metode dalam mencari dan mengumpulkan data dengan cara menyelidiki benda-benda yang bersipat tertulis seperti catatan, transkip, buku-buku, peraturanperaturan, notulen rapat, agenda dan sebagainya (Arikunto, 2014). Teknik dokumentasi dilakukan dengan cara mengumpulkan datadata yang bersifat tertulis tentang kondisi objektif objek penelitian yang berupa data siswa, data guru, arsip-arip, surat-surat, keadaan letak geografis dan segala hal yang berhubungan dengan penelitian.

Kuisioner yang juga dikenal sebagai angket merupakan teknik pengumpulan data yang dilakukan dengan cara memberikan seperangkat pertanyaan atau pernyataan tertulis kepada responden untuk dijawab (Subana, 2002). Pada penelitian ini angket disebarkan pada peserta didik SMP di Samarinda, kemudian dikumpulkan kembali untuk diolah datanya sebagaimana yang diperlukan oleh peneliti. Indikatorindikator instrument yang digunakan adalah pengembangan dari variabel pemahaman konsep salat (X) dengan kedisiplinan peserta didik (Y), merupakan materi pokok yang kemudian dijabarkan menjadi sejumlah pertanyaan atau pernyataan dalam angket.

Instrumen dikembangkan dengan menggunakan skala likert dengan alternative jawaban yaitu: alternatif selalu skor 4, alternatif sering skor 3, alternatif kadangkadang dengan skor 2 dan alternatif tidak pernah diberi skor 1 (Sugiyono, 2017). Pengumpulan 

dengan Kedisiplinan Peserta Didik (Ai Ilis)

data yang utama dengan menggunakan hasil jawaban siswa terhadap angket, adapun sebagai bahan pendukung lainnya yaitu dengan menggunakan hasil observasi dan dokumentasi di lapangan agar dapat mempermudah peneliti dalam penyususnan laporan ini.

D. Analisis Data

Analisis data merupakan sebuah proses mencari dan menyusun secara sistematis data yang diperoleh dari hasil pengisian angket oleh responden, catatan dan bahan lainnya. Kemudian data yang telah diperoleh diolah dengan menggunakan rumus-rumus statistik. Data kuantitatif yang telah dikumpulkan dalam penelitian korelasional, diolah dengan rumusrumus statistik yang sudah disediakan baik secara manual maupun dengan menggunakan program. Sebelum dilakukan analisa data terlebih dahulu dilakukan beberapa persyaratan pengujian: uji validitas, reliabilitas dan normalitas, autokorelasi, linieritas dan homogenitas kemudian dilakukan analisa data dan analisis uji hipotesis. Teknik analisis data yang dipergunakan untuk menganalisis berbagai pengaruh variabel data dipergunakan uji analisis regresi linier berganda.

Metode yang digunakan untuk menganalisis data pada penelitian ini adalah analisis Korelasi Ganda bertujuan untuk mengetahui korelasi antara variabel pemahaman konsep salat dengan kedisiplinan peserta didik baik secara parsial dengan rumus sebagai berikut:

$$
\begin{aligned}
& R_{x 1 x 2 y} \\
& =\sqrt{\frac{r_{x 1 y}^{2}+r_{x 2 y}^{2}-2 \cdot\left(r x \cdot y_{1}\right) \cdot\left(r x_{2} y\right) \cdot\left(r x_{1} x_{2}\right)}{1-r_{x_{1} x_{2}}^{2}}}
\end{aligned}
$$

Kemudian dalam proses perhitungannya dilakukan melalui software program SPSS for Windows versi 20. Kuat atau lemahnya hubungan pemahaman konsep salat terhadap kedisiplinan 
peserta didik $\mathrm{Y}^{\prime}=\mathrm{a}+b_{1} X_{1}+$ $b_{2}+X_{2}$ (Sugiyono, 2017).

Koefisien korelasi digunakan untuk mengetahui korelasi antara variabel independen (X) terhadap variabel dependen (Y). Perhitungan ini dinyatakan dengan rumus: $F_{h}=\frac{\frac{R^{2}}{k}}{\left(1-R^{2}\right) /(n-k-1)}$ ( Sugiyono, 2017).

Koefisien Determinan $\left(R^{2}\right)$ Untuk mengukur seberapa baik garis regresi cocok dengan datanya untuk mengukur persentase total variasi Y yang dijelaskan oleh garis regresi digunakan konsep koefisien determinasi $\quad\left(R^{2}\right), \quad$ koefisien determinasi $\left(R^{2}\right)$ didefinisikan sebagai proposisi atau persentasi dari total variasi variabel dependen $\mathrm{Y}$ yang dijelaskan oleh garis regresi (variabel devenden $\mathrm{Y}$ ). $\mathrm{KD}=r^{2} \mathrm{x}$ $100 \%$ (Riduwan, 2015).

Uji hipotesis digunakan untuk jawaban suatu hipotesis teoritik ke dalam hipotesis empirik (Sugiyono, 2014). Uji hipotesis yang digunakan yaitu uji t dan uji f, dimana Uji ketepatan model Uji t yaitu untuk menguji bagaimana korelasi masing-masing variabel bebas secara sendiri-sendiri terhadap variabel terkaitnya, untuk mengetahui ditolak atau diterimanya hipotesis maka dapat dilihat dari nilai signifikansi < 0,05. $t_{\text {hitung }}=\frac{r \sqrt{n-2}}{\sqrt{1-r^{2}}}$ (Sugiyono, 2017).

Selanjutnya untuk mengetahui signifikansi Korelasi Ganda dicari $F_{\text {hitung }}$ kemudian dibandingkan dengan $F_{\text {tabel }}$ dengan rumus: $\quad F_{\text {hitung }}=\frac{\frac{R^{2}}{k}}{\frac{\left(1-R^{2}\right)}{n-k-1}}$ Kaidah pengujian signifikansi: Jika F hitung $\geq$ F tabel, maka tolak Ho artinya signifikansi dan $\mathrm{F}$ hitung $\leq$ F tabel, maka terima Ho artinya tidak signifikan Taraf signifikan: $\alpha$ $=0,01$ atau $\alpha=0,05$ (Subana \& Rahardi, 2004).

Pembuktian hipotesis berdasarkan analisis korelasi 
Ganda yang perhitungannya melalui program SPSS selain itu juga dapat dilihat dengan membandingkan antara nilai Sig.(t) dan Sig.(F) dengan $\alpha(0,05)$ pada output SPSS. Jika Sig.t dan Sig.F lebih kecil dari 0,05 berarti hipotesis alternative (Ha) tersebut dapat dibuktikan kebenarannya. Sebaliknya jika Sig.t dan Sig.F lebih besar dari 0,05 maka hipotesis ditolak (tidak terbukti kebenarannya).

\section{HASIL DAN} PEMBAHASAN

Berdasarkan

hasil pengamatan yang didapatkan pada saat observasi awal menunjukkan ada tiga Sekolah yang terdapat di Samarinda berdasarkan letak daerahnya yang dibutuhkan oleh peneliti dalam menunjang kegiatan penelitian yaitu SMP Negeri 2, SMP Negeri 4 dan SMP Negeri 21 Samarinda. Ketiga SMP Negeri tersebut dengan akreditasi A dan merupakan sekolah dengan memiliki keunggulan dari berbagai program, prestasi dan penghargaan yang dicapai untuk menjadi contoh bagi Sekolah lainnya di Samarinda. Setelah melakukan observasi kemudian mengumpulkan data premier yang dibutuhkan yaitu dengan penyebaran angket yang terdiri dari 20 item, dimana 10 item pernyataan untuk pemahaman konsep salat, dan 10 item pernyataan untuk kedisiplinan. Seluruh pernyataan sudah diuji dengan uji validitas dan reliabilitas kemudian hasilnya diuji dengan uji normalitas, autokorelasi, linieritas dan homogenitas, selanjutnya dilakukan analisa data dan analisis uji hipotesis.

Berdasarkan hasil perhitungan menunjukkan bahwa butir instrumen dinyatakan valid apabila $r_{\text {hitung }}$ lebih besar daripada $r_{\text {tabel }}$. Bila menggunakan $r_{\text {tabel }} \mathrm{n}=$ 94 dan taraf kepercayaan 99\% dengan tingkat kesalahan $1 \%$ maka 
$r_{\text {tabel }}$ adalah 0,2617. Maka semua butir soal dikatakan valid. Berkaitan dengan pengujian validitas instrument menurut (Riduwan, 2015) menjelaskan bahwa validitas suatu ukuran yang menunjukan tingkat keandalan suatu alat ukur. Kemudian untuk menguji reliabilitas instrumen digunakan rumus Alfa Cronbach dengan menggunakan perhitungan bantuan SPSS ver.20 for windows (Riduwan, 2015). Berdasarkan hasil yang diperoleh pada Cronbach's Alfa sebesar 0,599. dan terletak pada taraf reliabilitas moderat, dan dapat diterima sebagai alat pengumpul data karena instrumen tersebut memenuhi kriteria moderat. Jadi pada kesimpulannya angket yang disebar di SMPN 2, SMPN 4 dan SMPN 21 telah dapat memenuhi syarat untuk dijadikan sebagai alat pengumpul data yang kemudian hasilnya dapat dijadikan sebagai alat ukur oleh peneliti dalam menghitung Korelasi Pemahaman konsep salat terhadap kedisiplinan peserta didik.

Pengujian selanjutnya adalah pengujian normalitas dipergunakan Test of Normality. Tes ini mencakup perhitungan distribusi frekuensi kumulatif yang akan terjadi di bawah distribusi teoritisnya, serta membandingkan distribusi frekuensi komulatif hasil observasi. Tes ini menetapkan suatu titik dimana kedua distribusi itu yang teoritis dan yang terobservasi memiliki perbedaan terbesar. Bila hasil uji probabilitas dan signifikansi Kolmogorov Smirnov lebih kecil dari 0,05 berarti distribusi tidak normal, dan sebaliknya bila lebih besar maka distribusi normal (Sugiyono, 2017). Berdasarkan hasil uji Kolmogorov-Smirnov diperoleh indeks probabilitas 1,005 lebih besar dari 0,05 dan signifikan sebesar 0,265 lebih besar dari 0,05 yang berarti data pemahaman 
konsep salat dengan kedisiplinan peserta didik berdistribusi normal.

Subana (2000) menyatakan bahwa Uji autokorelasi digunakan untuk mendeteksi ada atau tidaknya autokorelasi antar variabel predictor yang diteliti. Untuk melihat autokorelasi dalam penelitian ini menggunakan $\mathrm{Uji}$ Durbin-Waston (DW-Test) yang penghitungannya menggunakan software program SPSS versi 20. Keputusan ada tidaknya autokorelasi, yakni bila nilai DW berada diantara $d_{u}$ sampai dengan 4 - $d_{u}$, maka koefisien autokorelasi sama dengan nol, dalam arti tidak ada auto korelasi antar variabel yang diteliti. Berdasarkan dari hasil penelitian DW-Test menunjukkan bahwa nilai Durbin-Waston sebesar 1.865 yang berarti data variabel pemahaman konsep salat dan kedisiplinan peserta didik tidak ada autokorelasi.

Uji linieritas bertujuan untuk mengetahui apakah dua variabel mempunyai hubungan yang linier atau tidak secara signifikan (Subana, 2000). Pengujian menggunakan Test for Linierity pada taraf signifikansi 0,05. Dasar pengambilan keputusan dalam uji linieritas, yakni jika nilai probabilitas lebih besar dari 0,05 atau signifikansi linierity kurang dari 0,05 $(\rho>0,05 ;$ sig $>0,05)$, maka hubungan antara variabel $\mathrm{X}$ dengan $\mathrm{Y}$ dinyatakan linier. Sebaliknya nilai probabilitas lebih kecil dari 0,05, maka hubungan variabel dinyatakan tidak linier. Berdasarkan hasil uji linieritas dapat dinyatakan, bahwa variabel pemahaman konsep salat mimiliki hubungan yang linier dengan kedisiplinan peserta didik.

Uji homogenitas digunakan untuk mengetahui varian dari beberapa populasi sama atau tidak. Asumsi yang mendasari dalam analisis of varians bahwa varian beberapa populasi adalah sama. 
Dasar pengambilan keputusan jika nilai signifikansi adalah $<0,05$, maka dikatakan bahwa varian dari dua atau lebih kelompok populasi data adalah sama (Subana, 2000). Berdasarkan hasil uji homogenitas menunjukkan signifikansi homogenitas varian variabel kurang dari 0,05 yaitu sebesar 0,005. Dengan kata lain, asumsi homogenitas variansi dapat dipenuhi.

Pengujian korelasi dengan menggunakan uji korelasi product moment dari pearson correlation (Riduwan, 2015) dengan bantuan SPSS 20 antara invariabel independen pemahaman konsep salat dengan variabel dependen kedisiplinan peserta didik. Beradarkan hasil uji person korelasi (pearson correlation), diperoleh pemahaman konsep salat $\mathrm{r}=0,613, \quad$ tanda $* *$ mengindikasikan bahwa $H_{O}$ dapat ditolak. Semakin besar "r" mengindikasikan pula semakin besar korelasi. Dari nilai $r$ kedisiplinan $=0,613$ mengindikasikan bahwa pemahaman konsep salat berkorelasi kuat terhadap kedisiplinan peserta didik. Hasil perhitungan diperoleh sig. pemahaman konsep salat $=0,000$. Karena taraf signifikan $\propto=$ 0,05>0,000, maka $H_{o}$ ditolak, jadi pemahaman konsep salat berkorelasi dengan kedisiplinan peserta didik dan korelasi ini signifikan pada tingkat kepercayaan 5\%. Selain taraf signifikansi $\quad 5 \% \quad$ korelasi pemahaman dengan kedisiplinan peserta didik juga signifikansi pada $1 \%$.

Koefisien determinan pada regresi linier sering diartikan sebagai seberapa besar kemampuan variabel bebas dalam menjelaskan varian terikatnya. Secara sederhana koefisien determinan dihitung dengan mengkuadratkan koefisien korelasi ( $\mathrm{R}$ squaere) (Subana, 
2000). Berdasarkan hasil penelitian diperoleh korelasi antara pemahaman konsep salat dengan kedisiplinan peserta didik dalam uji korelasi berganda. Berdasarkan hasil perhitungan diperoleh koefisien determinasi $\left(R^{2}\right)=0,376$ yang berarti dimensi pemahman konsep salat memiliki kontribusi korelasi sebesar $37,6 \%$ rata-rata dengan kedisiplinan peserta didik, sisanya $66,4 \%$ diterangkan dengan variabel lainnya.

Pengujian hipotesis ini dimaksudkan supaya mengetahui apakah hipotesis yang diajukan ditolak atau diterima pada tingkat signifikansi tertentu (Subana, 2000). Dengan menggunakan analisis korelasi ganda dan uji korelasi sederhana, akan diperoleh tidak atau ada hubungan tetapi seberapa besar kekuatan hubungan yang terjadi antara dua variabel bebas dan variabel terikat baik secara sendiri maupun secara bersama. Uji hipotesis dilakukan dengan menggunakan program SPSS versi 20 for windows.

Subana (2000) menyatakan bahwa uji $F$ digunakan untuk menguji ada tidaknya korelasi variabel bebas terhadap variabel terikat secara parsial. Berdasarkan analisis korelasi ganda diperoleh nilai $F_{\text {hitung }}=56,589$ dan tabel distribusi F diperoleh 3,09. Karena $F_{\text {hitung }}>F_{\text {tabel }}$ maka $H_{O}$ ditolak. Pada tingkat signifikan diperoleh $\operatorname{sig}=0,000$ dan $\propto=0,05$. Karena $\propto$ $=0,05>\operatorname{sig}=0,000$, maka $H_{o}$ ditolak. Dari dua cara pengambilan kesimpulan diperoleh hasil analisis yang sama bahwa $H_{o}$ ditolak. Artinya terdapat korelasi antara pemahman konsep salat dengan kedisiplinan peserta didik.

Subana (2000) menyatakan bahwa Uji t dimaksudkan untuk mengetahui seberapa besar hubungan variabel dependen (pemahman konsep salat) secara individu menerangkan variabel independen (kedisiplinan peserta 
didik). Dari hasil perhitungan uji $t$ pemahaman konsep salat dengan kedisiplinan peserta didik diperoleh $t_{\text {hitung }}$ pemahaman $=$ 7.523 dan tabel distribusi t 1,989 Karena $t_{\text {hitung }}>t_{\text {tabel }}$ maka $H_{o}$ ditolak. Pada tingkat signifikan diperoleh sig $=0,000$ dan $\propto=0,05$. Karena $\propto=0,05>\operatorname{sig}=0,000$, maka $H_{o}$ ditolak. Dari dua cara pengambilan kesimpulan diperoleh hasil analisis yang sama bahwa $H_{O}$ ditolak. Artinya terdapat korelasi antara pemahaman konsep salat dengan kedisiplinan peserta didik.

\section{KESIMPULAN}

Berdasarkan pembahasan dari hasil penelitian yang telah dijelaskan, hipotesis yang diterima pada penelitian ini adalah $H_{a}$ yaitu, pemahaman konsep salat memiliki korelasi yang signifikan terhadap kedisiplinan peserta didik Sekolah Menengah Pertama Negeri di Samarinda. hal ini juga ditunjukkan berdasarkan hasil perhitungan didapatkan korelasi sebesar 37,6\% dengan nilai $r \quad 0,613$ yang menunjukkan adanya korelasi antara pemehaman konsep salat dengan kedisiplinan peserta didik Sekolah Menengah Pertama Negeri di Samarinda. hal tersebut mengindikasikan, pentingnya peran pendidik dan stakeholder lainnya dalam memperhatikan kemampuan pemahaman konsep salat pada peserta didik sehingga dengan pemahaman konsep salat yang tinggi, yang kemudian akan mempengaruhi kedisplinan pada peserta didik.

Peran yang dapat dilakukan oleh pendidik antara lain dapat mengoptimalkan waktu pembelajaran pendidikan agama Islam khususnya untuk lebih memperhatikan peserta didik atas pemahaman konsep salat. Kemudian dengan pemahaman konsep salat pada peserta didik diharapkan untuk dapat merealisasikannya dalam kehidupan, pendidik bisa membuat 
program-program mengenai pemahaman konsep salat yang kaitannya dengan pelaksanaan salat tinggi pada peserta didik, akan disekolah saat jam pembelajaran di membentuk pribadi peserta didik sekolah. Sehingga dengan yang disiplin.

\section{DAFTAR PUSTAKA}

Arikunto, S. (2014). Prosedur Penelitian Suatu Pendekatan Praktek. Jakarta: Rineka Cipta.

Annisa, R. (2016). Meningkatkan Pelaksanaan Tatacara Shalat Melalui Metode Kinestetik Bagi Siswa Tunanetra (Single Subject Research Di Slb Wacana Asih Padang). E-Jupekhu (Jurnal Ilmiah Pendidikan Khusus), 5 (1), 1-12.

Daradjat, Z. (2011). Ilmu Pendidikan Islam. Jakata: Bumi Aksara.

Daryanto. (2008). Evaluasi Pendidikan. Jakarta: PT Rineka Cipta.

Departemen Agama RI. (2009). Al-Qur'an. Bandung: J-Art.

Muhaimin. (2002). Paradigma Pendidikan Islam Upaya Mengefektifkan Pendidikan Agama Islam di sekolah. Bandung: PT Remaja Rosda Karya.

Nawawi, A. S. (2014). Panduan Praktis dan Lengkap Shalat Fardu dan sunnah. Jakarta: Amzah.

Nuraeni, N. (2008). Tuntunan Shalat Lengkap dan Benar. Jakarta: PT Buku Kita.

Sari, R. O., Pitoewas, B \& Yanzi, H. (2018). Pengaruh Shalat Berjamaah Terhadap Pembinaan Karakter Religius Peserta Didik Kelas VIII, 11 (11), $1-15$.

Qodar, L., Wijaya \& Amilda. (2017). Pelaksanan Ibadah Sholat dan Pengaruhnya Terhadap Etos Kerja, 1 (1), 1-14.

Rasyid, S. (2007). Fiqih Islam. Bandung: Sinarbaru Algensindo. 
Subana \& Rahardi, M. (2000). Statistik Pendidikan. Bandung: Pustaka Setia.

Raudlatun dkk. (2009). Tuntunan Shalat Praktis Dilengkapi Dalil, Dzikir dan Doa. Jakarta: Qultum Media.

Reza, I. F. (2015). Efektivitas Pelaksanaan Ibadah dalam Upaya Mencapai Kesehatan Mental. PSIKIS-Jurnal Psikologi Islami, 1 (1). 105-115

Riduwan. (2015). Metode dan Teknik Menyusun Proposal Penelitian. Bandung: Alfabeta.

Rifa'i, Moh. (2016). Risalah Tuntunan Shalat Lengkap. Semarang: PT Karya Toha Putra.

Subana dkk. (2000). Statistik Pendidikan. Bandung: Pustaka Setia.

Sugiyono. (2017). Metode Penelitian Pendidikan Pendekatan, Kuantitatif, Kualitatif dan $R \& D$. Bandung: Afabeta. . (2014). Metode Penelitian Bisnis cet ke-8. Bandung: Pusat Bahasa.

Sukmadinata, N. S. (2012). Metode Penelitian Pendidikan. Bandung: PT Remaja Rosdakarya.

UU. No. 20 Tahun 2003 tentang Sistem Pendidikan Nasional, pasal 3.

Uhbiyati, N. (2005). Ilmu Pendidikan Islam. Bandung: Pustaka Setia.

Zaitun, S. H. (2013). Implementasi Shalat Fardu Sebagai Sarana Pembentuk Karakter Mahasiswa Universitas Maritim Raja Ali Haji Tanjungpinang. Jurnal Pendidikan Agama Islam-Ta'lim, 11 (2), 153-168. 